\title{
Phan Chau Trinh's ideology of the position and role of the people and its significance in promoting the role of the people in Vietnam today
}

\author{
Tran Mai Uoc ${ }^{1}$ \\ Banking University of Ho Chi Minh City, Vietnam \\ E-mail: maiuoctran@gmail.com \\ Vu Thi Thu Huyen ${ }^{2}$ \\ E-mail: vuhuyen@tdc.edu.vn \\ Thu Duc college of Technology \\ Tran Thi Hoa $^{3}$ \\ E-mail: hoatranhn1986@gmail.com \\ Tran Dai Nghia University
}

\begin{abstract}
*Corresponding Author's: Tran Mai Uoc, Banking University of Ho Chi Minh City, Vietnam, 36 Ton That Dam Street, District 1, HCMC, 70000, Vietnam. Tel: (84) 948-888-070. E-mail: maiuoctran@gmail.com
\end{abstract}

Abstract: Phan Chau Trinh (1872 - 1926) was a leader of the Duy Tan Movement. With his conception of the position and role of the people, he left a bold mark on the nation's development history from the end of the nineteenth century to the beginning of the twentieth century. From analyzing and clarifying the main contents and limitations of Phan Chau Trinh's conception of the position and role of the people, the article has also raised its meaning for promoting the role of the people in the present period.

Keywords: Phan Chau Trinh; people; the role of the people; people's position

\section{Introduction}

During the late 19th and early 20th centuries, the French colonialists invaded and turned our country into a colonial, semi-feudal society. Vietnamese feudalism and Confucian ideology are increasingly powerless against the demands of the fight against foreign aggression for national independence. In that context, Phan Chau Trinh (1872 - 1926) was an active figure of the renewal and reform movement. He advocated reform of the political system with all its gravity and urgency. With what had been experienced, history has also recorded and evaluated, Phan Chau Trinh was the earliest democratic thinker among the progressive patriotic dignitaries at that time.

When studying Phan Chau Trinh's conception of the position and role of the people in Phan Chau Trinh's ideological system, we can see that, despite new, revolutionary and progressive contents, showing fervent patriotism and high hatred of the enemy as well as reflecting the contemporary times, associated with economic, political, cultural and social conditions in the early twentieth century, but the the most important issue was still independence for the nation. National independence was the ultimate goal of Phan Chau

\footnotetext{
${ }^{1}$ Tran Mai Uoc: Assoc. Prof. Ph.D. in Philosophy, Banking University HCMC, Ho Chi Minh City, Vietnam

${ }^{2}$ Vu Thi Thu Huyen: Ph.D. in Philosophy, Thu Duc college of Technology, Vietnam

${ }^{3}$ Tran Thi Hoa: Ph.D. in Philosophy, Tran Dai Nghia University, Vietnam
} 
Trinh's democratic thought. The content of the position and role of the people in Phan Chau Trinh's conception was expressed through the fact that the people were the rulers of the country, the country was the master of the people, opposing the thought on "Worship the King" (Tôn Quân Quyền) of which Phan Chau Trinh was the leader. Until now, in retrospect, it is still valid and meaningful for Vietnam today in promoting the role of the people in the current period of renovation and integration.

\section{Materials, methods and techniques}

\section{Theoretical basis}

Based on the theoretical basis of Marxism-Leninism, Ho Chi Minh's thought, guidelines and policies of the Party and State on teaching, researching and studying political theory subjects, social economic development.

\section{Practical basis}

The process of leadership, direction and implementation of the Party, State, and localities (higher education institutions) in the research, teaching and learning of political theory subjects.

\section{Methods}

The article uses dialectical materialism and historical materialism in research and specific methods include: analysis, synthesis, logic and history.

\section{Techniques}

The article using the technique of document analysis are the works of Phan Chau Trinh, mainly the Anthology of Phan Chau Trinh, Da Nang Publishing House in 1995 by Nguyen Van Duong as well as a system of related documents, research, teaching and learning political theory subjects in particular and Vietnam's socio-economic development in general.

\section{Content}

The formation of Phan Chau Trinh's conception of the position and role of the people was closely related to the socio-historical conditions of Vietnam and the world in the late 19th century and early 20th century. On the other hand, it was also influenced by the patriotic ideology of the Vietnamese nation, the Tan Thu ideology and the Renovation thought of the patriotic and progressive intellectual class, which appeared in the 19th century. In general, Phan Chau Trinh's conception of the position and role of the people did not arise on the basis of the emerging bourgeois economic and social character, but on the basis of the national spirit, faced the weakness of the feudal system, had accessed to the progressive ideological trends outside impacting on Vietnam at that time. Therefore, the voice of Phan Chau Trinh was the common voice of the nation, represented by a part of the patriotic feudal sages who were on the way to find a new truth, with a passionate patriotic spirit, loyalty and high spirit of hatred for the enemy, with the most important goal of independence for the nation.

\subsection{Overview of the content of Phan Chau Trinh's thought on the position and role of the people}

Phan Chau Trinh said that in a country, the people holded the most important position. The idea that the people were the master of the country, the country was the master of the people, was opposed to the thought of "Worship the King" (Tôn Quân Quyền), which was in stark contrast to the Confucian point of view, was a fundamental thought shift from monarchy to democracy. That was a very new thing in Phan Chau Trinh's political thought compared to his contemporaries, a breakthrough compared to the feudal political 
thought of thousands of years. Stemming from patriotism, compassion for the people's plight, and based on profound humanistic thought, Phan Chau Trinh believed that the goal of the self-governing regime was that the people were politically mastered, exercised their civil rights freely, such as basic rights: freedom of the festival, freedom of speech, freedom of thought, etc. The democracy that Phan Chau Trinh advocated to build was a democracy from below, which meant that the people had the most important position and role. The people's wisdom had been improved, the people's spirit had been revived, the people's livelihoods had prospered, the nation had been self-sufficient, and a civilized society, according to Phan Chau Trinh, was a guarantee for a substantive democracy, replacing the military owner. Therefore, democracy was associated with freedom, freedom was guaranteed by democracy. He wrote: "A race of people with a single drop of blood split, with the same language, in the land where our forefathers had shed their blood, sweat, and tears, to break the cauldron into a nation. If they had been handed down for four thousand years until then, they had been allowed to enjoy the rights in that land, live there, die and bury there, get rich because of it, poor and rely there, no one could forbid anything"4

In order to realize his democratic policies, a very important content in Phan Chau Trinh's thought is to awaken the people to understand their rights. The people who understand their rights will realize the revolutionary goal. Therefore, in democratic thought, Phan Chau Trinh emphasized the role and interests of the people, the people have the right to live and enjoy the rights and perform the noble sacred obligations to the country.

In order to make people understand their right to master, Phan Chau Trinh actively spread the content about the rights and obligations of the people. The aim was to make people aware of what he called moral ethics, or the relations of rights and obligations of people in families, nations and society. According to Phan Chau Trinh, moral ethics had developed from low to high: family morality, national morality, social morality. The Vietnamese people were weak because they only had a limited understanding of the relationship between king and subject, and did not know the relationship between the country and the people, so the people did not understand their rights and obligations. He wrote: "... the people in the country do not know what civil rights are, what is love for the country, what are their obligations?"5 . Limitations in social morality made people not know what a union is, what an organization is, which was due to the feudal system. He wrote: "The people do not know the union, do not respect the common good, because three or four hundred years ago, the students in the country became greedy for power and glory, and became false and flattered, know the king but do not know the people "6. Therefore, it was necessary to arouse the national spirit, because in the past, our people were very heroic and united, and knew how to defend each other. He said: "...the Vietnamese people in the early days also knew the union, knew the common good, knew many a little makes a mickle, not so lonely, lazy, and inert as today" ${ }^{7}$. From the correct perception of the state of the nation's decay during several hundred years of feudalism, Phan Chau Trinh believed that it was necessary to spread social morals to the people, awaken the people to make the people understand and know their rights and obligations

\footnotetext{
${ }^{4}$ Duong, N.V. (1995), Anthology Phan Chau Trinh, Da Nang Publishing House, p.774

${ }^{5}$ Duong, N.V. (1995), Anthology Phan Chau Trinh, Da Nang Publishing House, p. 722

${ }^{6}$ Duong, N.V. (1995), Anthology Phan Chau Trinh, Da Nang Publishing House, p. 777

${ }^{7}$ Duong, N.V. (1995), Anthology Phan Chau Trinh, Da Nang Publishing House, p. 777
} 
to the country and to the nation. He wrote: "Now, if Vietnam wants to be independent and free one day, the Vietnamese people must first have a union. But if you want to have a union, there is nothing better than spreading socialism among the Vietnamese people." Therefore, Phan Chau Trinh's democratic ideology has outstanding value in making people aware of the role of democracy. At the same point with Phan Boi Chau, Phan Chau Trinh had the concept of the relationship between people and country, national rights and civil rights, He wrote: "If you call it a country, you must have land and people" ${ }^{9}$, which was the most prominent dialectical relationship in bourgeois democratic thought in the early 20 th century in our country. So, in order for the people to understand their rights and obligations, what should the Vietnamese revolution do?

According to Phan Chau Trinh, first of all, it was necessary to build a new national theory, which could not be based on the traditional idea of totalitarian monarchy, Phan Chau Trinh said, must combine tradition with modernity, nation with the world . He wrote: "If we keep a little of our morality, absorb a little of European morality, bring it back together, and then expand it, it means that everyone in Vietnam knows their obligations to Vietnam. So that, not only Vietnam will be rich and strong in the future, but in this world any people who want to come and be parasitic on this land will not be able to despise us like today"

Phan Chau Trinh was very passionate about the nation's history. He affirmed that our nation is a "heroic, vigorous breed", with a history of heroic struggle and a good reputation forever. But Phan Chau Trinh was very indignant at the backward situation of the country, he compared the situation, psychology, and trends of the nation with the world situation, so we see that was very up-to-date on the situation. On this point, if compared with Phan Boi Chau, it can be seen that: they were the same, but their views became different. Phan Boi Chau also acknowledged the backwardness and pain of the homeland, but was emotional, so he built a heart-touching feeling. Phan Chau Trinh's poetry shows a disgruntled look. Phan Chau Trinh's way of education was to go completely into reality for people to be enlightened by specific situations by seeing, not by suggesting.

Phan Chau Trinh's national view was to be realistic to find the cause. This was a measure of face-to-face education. The cause of our nation's backwardness, according to Phan Chau Trinh, was mainly due to the feudal system that made "the people stupid, the country weak". Because of that, Phan Chau Trinh vehemently condemned the kings and mandarins. That was the difference of Phan Chau Trinh in terms of ethnicity, compared with the scholars and idealists of the time. It was also the national ideology, but the harm caused was not due to lack of patriotism, limited progress, insufficient resistance, but due to feudalism, harmed by kings and mandarins. Must knew the pain for that main cause.

Next, he pointed out what crimes the colonists had committed. It must be noted that here, although the Duy Tans and the Dong Du faction met each other, so did Phan Chau Trinh. But the emphasis was different. Phan Chau Trinh looked for the causes of the invading colonialists, their stupid tricks. The unique thing about Phan Chau Trinh compared to the modernists was that he always puts Vietnam in the modern world. He had a world view,

\footnotetext{
${ }^{8}$ Duong, N.V. (1995), Anthology Phan Chau Trinh, Da Nang Publishing House, p. 779

${ }^{9}$ Duong, N.V. (1995), Anthology Phan Chau Trinh, Da Nang Publishing House, p. 553

${ }^{10}$ Duong, N.V. (1995), Anthology Phan Chau Trinh, Da Nang Publishing House, p. 791
} 
not just a national vision. Patriots often pointed out the weaknesses of their people, on the basis of patriotism. Phan Chau Trinh's look was a modern look.

Since then, we see that Phan Chau Trinh's democratic thought had a higher development in quality than before. If in the past, democratic thought only stopped at opposing democracy with the monarchy in general, then here, democratic thought was associated with national independence, specific rights of the Vietnamese people, universal social category, not limited to the national category, the bourgeois democratic category. ${ }^{11}$ This represented the development and transformation of Phan Chau Trinh's thought and was also the basic premise for him to approach Marxism-Leninism.

The contradiction in political thought of Phan Chau Trinh is that, on the one hand, he upholds the role of democracy and civil rights stemming from the will of the people; but, on the other hand, he was consistent with the policy of relying on France, which was the invading empire, enslaving Vietnam to implement democracy. Phan Chau Trinh had been full of praise for French democracy: "Pháp luật dựa Lang sa làm chủ", a democracy that Phan Chau Trinh understands was for everyone. Because of such contradictions, the reality of that idea was very low and in fact, the French government had never considered him as an ally in the "civilization" in Indochina in general and Vietnam in particular.

Thus, Phan Chau Trinh's conception of the position and role of the people was basically expressed quite fully and systematically, making a bold impression in the early years of the twentieth century. Phan Chau's conception of the position and role of the people in political thought deserves an important position because it contributed to a turning point in our nation's history in the late 19th century and early 20th century XX.

\subsection{The limitation in Phan Chau Trinh's ideology about the position and role of the resident.}

Despite having new contents, revolution and progress represent the position and role of the people as the most important position in a country, ardent patriotism, and the will to save the country in Phan Chau Trinh's political thought. However, due to contemporary conditions and circumstances, there are still basic limitations in Phan Chau Trinh's political thought.

Firstly, in practical terms, our country was oppressed and exploited by colonial and feudal regimes over the historical era, and all human rights were taken away, leaving no circumstances for the new theory to be widely spread. Phan Chau Trinh assimilated the ideas of democracy and Western civilization through the Tan Thu and Tan Van, but he himself did not pose the problem of translating the national language to popularize in society, but he sought to deliver thoughts through his literature. Meanwhile, in Vietnamese society at that time, most of the population was illiterate, with low educational attainment, so the dissemination of ideology was still limited among the few middle-class people who knew Chinese. Therefore, the progressive, revolutionary ideas, expressing the fervent patriotism of Phan Chau Trinh only really affected a particular part of people in society at that time.

Phan Chau Trinh did not realize that in the imperialist stage, the progressive nature of the early French bourgeois revolution was just nostalgia for a bygone era. During the imperialist period, the constant anxiety of the French empire, as well as any other empire,

\footnotetext{
${ }^{11}$ Uoc, T. M (2017), Political thought of Phan Chau Trinh, Political Theory Publishing House, Hanoi, p.127
} 
was not only to cling to the colony and turn it into its forbidden garden but also to contain it, maintain it in a state of underdevelopment in all respects to keep their superiority over the indigenous population. Therefore, under the conditions of a colonial, semi-feudal society like ours at the beginning of the twentieth century, it was not possible to carry out any real reform to improve people's intellectual level and expand civil rights; There is no way to take each step forward definitely to gradually plan something else. Phan Chau Trinh naively believed in the "sincerity" of the French empire, while exaggerating the role of "integrity and talented mandarins" in a country where national sovereignty had completely belonged to the invasion force. Phan Chau Trinh did not realize that the prerequisite of all reforms for social progress was to have an independent government, free from the corruption of imperialists and oppression. From there, we can talk about Innovation, civil rights, and people's cultural standards. In Japan, in the success of the Duy Tan movement, except great conditions for the economy - society, having a government that does not depend on foreign countries when carrying out reform on all aspects was the prerequisites of Japan.

That negative factor also stems from Phan Chau Trinh's limited awareness of the meaning of the armed struggle. We agree with Phan Chau Trinh that armed struggle must be conditional, that in the context of Vietnam at the beginning of the twentieth century, the opportunity for the armed uprising has not yet appeared, but if we just base on that factor to come to the policy of "No need to exhort to fight the French", "Put aside the thought of violence", then that is a negative conclusion, only considering the immediate benefits, without considering the long-term consequences. That view also shows that, because of the awareness that it is not necessary to overthrow the invading government, also too enthusiastic about building the new society he dreams of, therefore, when assessing people and nationalities, Phan Chau Trinh only stopped at the external weaknesses without paying attention to the most basic expression, the essence of the national vitality is the tradition of rebellious, courageous struggle against the oppressive force. Despite including negative factors, Phan Chau Trinh's political thoughts and actions contributed to the awakening of our nation in the early twentieth century, promoting the revolutionary struggle of our people. at that time.

Secondly, in terms of perception, Phan Chau Trinh's conception of the position and role of the people has not yet created an ideology, a consistent, scientific, and radical philosophical basis, and is still influenced, as well as not completely free from the concept of Confucianism.

Phan Chau Trinh commented and argued that the patriotism of the South Vietnamese people has never ceased, only the bureaucratic autocracy with its obsolete academic system and its harsh laws is a poison to deadly. Therefore, the first thing to do is defeat the old monarchist ideology, destroy the dream of academics, and restore the soul of our country, from which to gradually come to independence and self-reliance. He focused on denouncing the evils in villages, officials, puppet kings, and wooden statues. The purpose at this time is to clearly show our people the corrupt and irrational nature of the contemporary social organization. In Phan Chau Trinh's mind, he has not yet escaped from the way of arranging the social order according to the four peoples. On the one hand, Phan Chau Trinh considers that scholars, farmers, workers, and merchants are all necessary for society, but on the other hand, Phan Chau Trinh still despises workers and commercial professions. Regarding the profession of the scholar, he praised "virtue 
integrity, helping the king and the people"; farming, he praised as "pure farming" but for technology, Phan Chau Trinh said that "there are some bad parts, so it's better to spend the third"; In business, he found that there was a bad habit of "swapping weights, making sure shrimp and fish, competing for edge". This shows that Phan Chau Trinh has not yet been able to overcome Confucian socialism.

In addition to criticizing Confucian thought and feudal and colonial society, we see that, in fact, Phan Chau Trinh does not criticize Confucianism for the purpose of completely overthrowing the ideology which they were taught, acquired, and passed on through the history of thousands of years of the political - social - educational system. Not only Phan Chau Trinh, but the Duy Tan reformists at that time only focused on criticizing the negative manifestations of Confucianism in front of the reality of Vietnamese society at the beginning of the twentieth century to renew the society, culture, and ideology of Vietnam comprehensively, gaining independence for the nation, freedom, and democracy for the people. The influence of Confucianism in terms of thinking and ideological methods, even those who strongly oppose Confucianism, are still quite strong. Therefore, Phan Chau Trinh has not yet critically criticized the worldview and methodology of Confucianism, not only because Confucianism did not co-exist with feudalism, so it did not die with it, but because the Confucianism, the categories of Confucian philosophy almost entered the subconscious of Confucian scholars at that time in general, including Phan Chau Trinh.

While promoting democracy, Phan Chau Trinh forgot the issue of eradicating the colonialists to gain national independence, he only realized the contradiction between the monarchy and the people but did not realize the most fundamental contradiction is between our people with the French colonialists. From the above point of view, we see that Phan Chau Trinh is politically ambiguous when relying on the colonialists to expect justice in front of the law of the bourgeoisie. For the colonial regime, even the most peaceful protest of the colonial people can be most brutally suppressed, there can be no equality for the law.

\subsection{Meaning of Phan Chau Trinh's ideology of position and the people's role in promoting the role of the people in Vietnam today}

When researching and finding Phan Chau Trinh's concept of the position and role of the people, it can be seen that if ignoring the limitations due to historical conditions, awareness levels, and class views, we can draw historical meanings for promoting the role of the people in the period of renovation and integration in Vietnam today.

\subsubsection{Determining the role of the people in the process of implementing major programs in Vietnam}

Since renovating and opening up to now, the trend of development of the market economy has trained and built up subjects having diverse interests. The various stakeholders will have different needs of benefits. These benefits can be done or not depending very much on the organizational level of the organization. Only beneficial corporations which have the nature of the regime or the new cultural organizations can promote the role of protecting the benefits of their organizations. In the strict mechanisms of market economy and the context of reforming and opening up more and more broaden, the people are the object that has contributed the most and also sacrificed most to the career of building the socialism in Vietnam. However, they are also the most disadvantaged class. To improve this situation, people have to gather together to build up 
cooperative organizations representing for their rights and benefits. Besides, they need to promote their role as a subject in constructing and developing the country in the context of innovation and integration.

The participation of citizens in the formulation of action programs aiming at national targets is considered as an important factor, determines the success or failure of the application of approaching development based on domestic resources and by the people employed. For example, while engaging in the process of building new rural areas with the support of the State, the people in the communities of the rural population will gradually be enhanced with skills and management competency to take full use of local and external resources. When considering the participation of the citizens in activities of rural development, the role of the people here is shown: the people know, the people discuss, the people contribute, the people do, the people check, people manage and the people benefit. Thus, the role of the people still follows a certain order, the order here is entirely consistent with the views of our Party 'the people as the foundation ", as well as the concept of Phan Chu Trinh when emphasizing the policy of building democracy from bottom to up, meaning that the people have the most important position and role. Therefore, here, the contents in enhancing the role of the citizens in participating in building the programs aiming at national goals or big plans concerning the development of the country in the current period to be understood: the people know meaning that the rights and obligations and the understanding of indigenous knowledge can contribute to the process of implementation. On the other hand, people fully grasp the information guidelines, programs, and implementation plans as well as the rights of local communities who are benefited. People discuss: including the participation of giving opinions of the people related to the policy, programs, plans, and solutions in the design, exploitation, organization, management, methods of financial management, etc. The people contribute meaning a factor which is not only in the category of material, money but also in the categorical perception of ownership and responsibility, increase self-awareness of each citizen in the community. Forms of contributing can be money, labor, and materials on-site or intellectual contributions. The people do meaning labor participation directly from the people in the activities related to the policy, programs, and plans. The people check means through programs and activities under the supervision and evaluation of the people, to implement the regulations on grassroots democracy of the Party and the State in general and improve the efficiency of quality of policy, programs, and plans are being implemented. The people manage that is the achievement of the activities that people participated. The program, planned after the completion of construction should be direct management of an organization by the people benefit designed to avoid the situation is not clear about the owner of the work, promoting proactive, positive and creative people to participate in maintenance and maintenance, especially of programs, plans, and major projects, associated with social security, social welfare of the people. The people enjoy the benefits that means the benefit that the policy, programs, plans, and activities bring.

\subsubsection{Focusing on renovating cadre work, building a contingent of cadres and civil servants who are capable and qualified to meet the requirements of building a socialist rule of law state of the people, by the people, for the people in Vietnam.}

Cadres in general and civil servants in the state apparatus, in particular, play a decisive role in the success or failure of the revolution, the effectiveness as well as efficiency of 
the state apparatus's operation. In a socialist rule of law state of the people, by the people, for the people, cadres and civil servants must meet the following requirements. Firstly, have professional qualifications to meet job requirements which we undertake. Secondly, be dedicated and diligent to work, show responsibility and work ethics while performing assigned tasks. Have a spirit of cooperation and help colleagues. Thirdly, strictly comply with the provisions of the law with a sense of selfdiscipline and strict disciplines, do not do anything contrary to conscience and public duties. Fourthly, respect for citizenship; be close to the people, listen to the people's opinions and aspirations, and humbly learn from the people; Finally, be exemplary in abiding by policies and laws, practice moral qualities, lifestyle, and working style.

\subsubsection{Promoting the power of the masses in the cause of Vietnam's construction and development}

Both practice and theory have proved that going through historical events deciding the destiny and lasting development of the country, the people always have actually significant roles and contributions. The people are the subject, deciding the development of history. The strength of the masses determines the success or failure of all revolutions. During his lifetime, President Ho Chi Minh emphasized and affirmed that "There is nothing in the sky as precious as the People. In the world, nothing is stronger than the united force of the People." "I . In all activities, our Party has always thoroughly grasped the idea of "The country considers the people as the root", defining revolution as the career of the people, by the people and for the people; considers meeting the people's practical interests and unifying the rights and obligations of citizens as the promotion to drive force mass movements. Besides, promoting the role of mastery, the strength of the people is the responsibility of the Party, the State, the Vietnamese Fatherland Front, and the organization of mass organizations.

In the coming time, to "strongly arouse patriotism, the will to strengthen the nation, the strength of the great unity of the whole nation and the aspiration to develop a prosperous and happy country"13, and to successfully implement the goals and tasks of socioeconomic development and improve people's living standards, the Party and State should strongly arouse patriotism, the will to self-reliance and self-reliance nation, aspiration to develop a prosperous and happy country. Accordingly, it is necessary to study and launch some movements to arouse all potentials and resources, create new motivations and breakthroughs for rapid and sustainable development. First of all, focusing on: (i), strongly developing science - technology and innovation, improving productivity, quality, efficiency, and competitiveness of the economy; (ii), building and developing culture and society, improving the people's material and spiritual life; (iii), improving the quality and effectiveness of the movement "all people unite to build a cultural life" and the movement in all fields, especially in the fields of defense, security, foreign affairs and Party, Government building aiming at mobilizing the masses of people to participate, creating positive effects on national construction, protection, and development. Most recently, with extremely complicated developments of the COVID-19 pandemic in the world, especially in India, as well as countries bordering Vietnam such as Laos and Cambodia, the outbreaks can occur on a large scale in our country at any time. In fact, in

\footnotetext{
${ }^{12}$ Ho Chi Minh (2000), Volume 8, National Politics Publishing House , Hanoi, p. 726

${ }^{13}$ Communist Party of Vietnam (2021), Document of the 13th National Congress of Deputies, National Political Publishing House - Su That, volume 1, Hanoi, p109
} 
the previous outbreaks of COVID-19, besides the drastic intervention of the government, the role of the people in disease prevention and control is very important. It is thanks to the promotion of the people's strength and the strict observance of the majority of the people that Vietnam has gradually pushed back the epidemic, brought the country back to a new normal state, and made the "double goal" that has developed the economy and ensuring the requirements of epidemic prevention and control in the same time. Now, when there is a risk that the next wave of COVID-19 may break out in Ho Chi Minh City, Hanoi, and provinces like Bac Giang, the departments, ministries, branches, and authorities from the Centre to the locality, there are new requirements, which was the participation of the people themselves. Each citizen needs to turn himself into an epidemic fighter. The people should comply strictly with the promulgated regulations on disease prevention and control. Also, be ready to denounce individuals and organizations that violate regulations on epidemic prevention and control. If every citizen participates in the fight against the disease, even though COVID-19 is complicated, with the developing variants of COVID-19, we can step by step control and repel in the near future.

\section{CONCLUSION}

Looking back on 35 years of implementing the innovation, Vietnam has gained great achievements, a sense of history, and developed strongly and comprehensively. The scale and level of the economy have been raised. Also, both the material and spiritual life of the citizens has been improved markedly. The country has never got the map, potential, position, and prestige as today. Therefore, this is pride, motivation, critical resources, and is the belief of Vietnam to overcome all difficulties and challenges for continuing firmly on the path of comprehensive and synchronic reforming and rapid and sustainable development of Vietnam in the next time. The achievements of the innovation mentioned above are results of the process of striving continuously, durably of the entire Party, people, and armed forces with many different objective and subjective reasons. Also, that is a continuation, legacy, complement, and development of the thousand-year historicalcultural tradition of Vietnam. In which, the ideas of innovating, renewing of culture, reforming politics-society of patriotic people in the period of the late nineteenth century and early twentieth century in general and fervently patriot Phan Chu Trinh in particular. If saying each progressive thinker is a step in the thought's history Vietnam, the concept of the position and people's role of Phan Chu Trinh will be a progressive step. It helped promote the history, like a wake for Vietnam's nation in the early years of the twentieth century.

\section{REFERENCES}

[1]. Communist Party of Vietnam (2021), Document of the 13th National Congress of Deputies, National Political Publishing House - Su That, volume 1, Hanoi [2]. Duong, N.V. (1995), Anthology Phan Chau Trinh, Da Nang Publishing House [3]. Ho Chi Minh (2000), Volume 8, National Politics Publishing House, Hanoi [4]. Kinh, L. T (2003), Phan Chau Trinh through new documents, Da Nang Publishing House

[5]. Uoc, T. M (2011), The impact of Chinese New Letters on Phan Chau Trinh's thought, Journal of Theoretical Education, No 10 
[6]. Uoc, T. M (2012), Education development thought of Huynh Thuc Khang and Phan Chau Trinh and historical significance, Journal of Science and Technology, Quang Nam, No. 110,111

[7]. Uoc, T. M (2017), Political thought of Phan Chau Trinh, Political Theory Publishing House, Hanoi 